Research Article

\title{
Zinc Sulphate and Boron-Based Foliar Fertilizer Effect on Growth, Yield, Minerals, and Heavy Metal Composition of Groundnut (Arachis hypogaea L) Grown on an Alfisol
}

\author{
Christopher Aboyeji ${ }^{D},{ }^{1}$ Oluwagbenga Dunsin $\left(\mathbb{D},{ }^{1}\right.$ Aruna O. Adekiya ${ }^{(D)}{ }^{1}$ \\ Chinomnso Chinedum, ${ }^{1}$ Khadijat O. Suleiman, ${ }^{1}$ Faith O. Okunlola, ${ }^{1}$ Charity O. Aremu, \\ Iyiola O. Owolabi, ${ }^{2}$ and Temidayo A. J. Olofintoye ${ }^{3}$ \\ ${ }^{1}$ Department of Crop and Soil, College of Agricultural Sciences, Landmark University, Omu-Aran, Kwara State, Nigeria \\ ${ }^{2}$ Faculty of Agro-Industry, Prince of Songkla University, Hat-Yai 90112, Thailand \\ ${ }^{3}$ National Horticultural Research Institute, P.M.B 5432, Idi-Ishin Ibadan, Nigeria \\ Correspondence should be addressed to Christopher Aboyeji; chrismuyiwa@yahoo.com
}

Received 7 March 2019; Accepted 13 June 2019; Published 9 October 2019

Academic Editor: Allen Barker

Copyright @ 2019 Christopher Aboyeji et al. This is an open access article distributed under the Creative Commons Attribution License, which permits unrestricted use, distribution, and reproduction in any medium, provided the original work is properly cited.

\begin{abstract}
Field experiments were conducted during 2016 and 2017 cropping seasons in the derived agro-ecological zone of Nigeria to study the combined and sole effect of zinc and boron fertilizers on the growth, seed yield, and quality of groundnut (Arachis hypogaea L). The experiment was laid out in randomized complete block design (RCBD), replicated four times. Three levels of zinc ( 0 , 4, and $\left.8 \mathrm{~kg} \cdot \mathrm{ha}^{-1}\right)$ and four levels of boron $\left(0,300,600\right.$, and $\left.900 \mathrm{ml} \cdot \mathrm{ha}^{-1}\right)$ were combined and evaluated. Groundnut seeds were analyzed at the end of the experiments to determine nutrient elements and some heavy metal contents. Data collected were subjected to Statistical Analysis of Variance using SAS 2000. Treatment means were compared using the Duncan multiple range test at 0.05 level of probability. The effect of zinc was not significant on the vegetative parameters, while application $8 \mathrm{~kg} \mathrm{Zn} \cdot \mathrm{ha}^{-1}$ significantly increased number of seeds, weight of seeds, seed yield per hectare, and seed quality though the values were similar to the application of $4 \mathrm{~kg} \mathrm{Zn} \cdot \mathrm{ha}^{-1}$ only on the seed yield and its parameters. Application of 600 and $900 \mathrm{ml} \mathrm{B} \cdot \mathrm{ha}^{-1}$ gave higher and statistically similar values for vegetative parameters, yield, and yield parameters, while $600 \mathrm{ml} \mathrm{B} \cdot \mathrm{ha}^{-1}$ significantly improved the seed quality. It can therefore be recommended that for optimum yield and seed quality, application of $8 \mathrm{~kg} \mathrm{Zn} \cdot \mathrm{ha}^{-1} \mathrm{combined}$ $600 \mathrm{ml} \mathrm{B} \cdot \mathrm{ha}^{-1}$ is sufficient in the study area without increasing the heavy metal concentration of groundnut seed.
\end{abstract}

\section{Introduction}

Groundnut (Arachis hypogaea L.) is a species of the legume or "bean" family (Fabaceae). It is an annual herbaceous plant that grows within $30-50 \mathrm{~cm}$ in height [1].

The worldwide groundnut is grown in 26.4 million hectares with a total production of 37.1 million metric tonnes and an average productivity of 1.4 metric th ha ${ }^{-1}$. Global production (2011) totaled 38.6 million tons, 95 percent of which occurred in developing countries, and major producers include China, India, Nigeria, USA, and Myanmar [2]. Rich in protein and oil fit for human consumption, groundnut (Arachis hypogaea) is principal to the financial and nutritional well-being of hundreds of millions of farmers and consumers across the semi-arid tropics.

Mineral nutrition of plants is important for controlling physiological and biochemical processes of plants [3]. Micronutrients are essential elements for life [4], as they play key roles in the release of carbon dioxide and in optimizing the function of vitamin A and the immune system [5]. The amount of trace elements found in soil is sometimes so small that they are barely detectable, but without them, plants fail to thrive [6]. Micronutrient deficiency can greatly affect 
plant yield and quality and the health of domestic animals and humans negatively [7]. Application of micronutrients through foliage can be from 10 to 20 times as efficient as soil application [8].

Boron (B) plays an important role in the physiological process of plants, such as cell elongation, cell maturation, meristematic tissue development, and protein synthesis [9]. The need for B application in groundnut is therefore, to increase the growth, development, and at the same time to increase the yield of crops. The application of B also promotes the absorption of $\mathrm{N}$ by groundnut and increases the plant height, plant dry weight, and the total number of pods [10].

Globally, zinc ( $\mathrm{Zn})$ is now recognized as the 5th major nutrient deficiency in human beings mainly due to its deficiency in the soil. Zn has specific and essential physiological functions in plant metabolism, influencing yield and quality [11].

In determining the yield and quality of groundnut, the role of $\mathrm{Zn}$ and B is much pronounced. Restricted availability of these nutrients in sandy soil greatly impairs the yield of groundnut [12].

Legumes are considered the most important source of food after cereals in the world, as they are main sources of protein and energy for humans. Due to its nutritional values and economic importance, it is necessary to develop new methods for increasing the crop production [13]. Nutrient deficiency in soil is one of the important factors for poor productivity of pulses, while nutrient management is one of the key agronomic factor affecting crop yields.

The continuous and imbalanced use of selected inorganic fertilizers (NPK) has resulted in deterioration of soil health, higher cost of production, and decline in factor productivity [14]. The objective of the study was to evaluate the response of Arachis hypogaea L. to micronutrient fertilizer application with a view to determining the requirements for nut quality and possible heavy metal accumulation on an alfisol of derived guinea savanna.

\section{Materials and Methods}

The experiment was carried out at the Teaching and Research farm, Landmark University, Omu-Aran, Kwara State (latitude $8.9^{\circ} \mathrm{N}$ and longitude $50^{\circ} 61^{\circ} \mathrm{E}$.), located at the derived agro-ecological zone of Nigeria. It has an annual rainfall pattern which extends between the months of April and October with average annual rainfall of between $600 \mathrm{~mm}$ and $1500 \mathrm{~mm}$. The peak rainfall is in May-June and SeptemberOctober while the dry season is between November and March. Precropping soil samples $(0-30 \mathrm{~cm}$ depth) were collected from each plot during the cropping seasons and bulk to determine the physicochemical properties of the soil.

The land was ploughed once and harrowed twice to give a well-pulverized soil after which it was ridged. Thereafter, the field layout was carried out to mark out the appropriate number of treatment plots. The size of each plot in the experiment was $4.2 \mathrm{~m} \times 8 \mathrm{~m}=33.60 \mathrm{~m}^{2}$ and there were 12 plots per replicate $\left(33.60 \mathrm{~m} \times 12 \mathrm{~m}=403.20 \mathrm{~m}^{2}\right)$ which was replicated four times. The size of the whole experimental plot was
$430.20 \mathrm{~m}^{2} \times 4 \mathrm{~m}=1,612.80 \mathrm{~m}^{2}$. Phosphorus fertilizer $(18 \%$ single superphosphate) was applied at planting at the rate of $54 \mathrm{~kg} \mathrm{P}_{2} \mathrm{O}_{5} \cdot \mathrm{ha}^{-1}$ to all the plots as basal dose.

Treatments consisted of zinc in the form of $\mathrm{ZnSO}_{4}$ (zinc sulphate) and boron in the form of $\mathrm{C}_{2} \mathrm{H}_{10} \mathrm{BNO}_{4}$ (boron ethanolamine) which were applied by side placement and foliar application, respectively. Three levels of zinc $(0,4$, and $\left.8 \mathrm{~kg} \cdot \mathrm{ha}^{-1}\right)$ and four levels of boron $(0,300,600$, and $900 \mathrm{ml} \cdot \mathrm{ha}^{-1}$ ) were combined and evaluated as follows: $-\mathrm{B}_{0} \mathrm{Z}_{0}\left(\mathrm{~T}_{1}\right), \mathrm{B}_{300} \mathrm{Z}_{0}\left(\mathrm{~T}_{2}\right), \mathrm{B}_{600} \mathrm{Z}_{0}\left(\mathrm{~T}_{3}\right), \mathrm{B}_{900} \mathrm{Z}_{0}\left(\mathrm{~T}_{4}\right), \mathrm{B}_{0} \mathrm{Z}_{4}\left(\mathrm{~T}_{5}\right)$, $\mathrm{B}_{300} \mathrm{Z}_{4}\left(\mathrm{~T}_{6}\right), \mathrm{B}_{600} \mathrm{Z}_{4}\left(\mathrm{~T}_{7}\right), \mathrm{B}_{900} \mathrm{Z}_{4}\left(\mathrm{~T}_{8}\right), \mathrm{B}_{0} \mathrm{Z}_{8}\left(\mathrm{~T}_{9}\right), \mathrm{B}_{300} \mathrm{Z}_{8}\left(\mathrm{~T}_{10}\right)$, $\mathrm{B}_{600} \mathrm{Z}_{8}\left(\mathrm{~T}_{11}\right)$, and $\mathrm{B}_{900} \mathrm{Z}_{8}\left(\mathrm{~T}_{12}\right)$. The experiment was laid out in randomized complete block design (RCBD) with splitplot arrangement replicated four times.

Four groundnut seeds commonly grown in the derived savanna of Nigeria were manually sown per hole at interand intrarow spacing of $0.70 \mathrm{~m} \times 0.2 \mathrm{~m}$ and at a depth of about $5 \mathrm{~cm}$ on a well-prepared ridge. Plants were thinned to two plants per stand two weeks after sowing. At two weeks after sowing, zinc fertilizer was manually applied by side placement $5-8 \mathrm{~cm}$ away from the base of the plant, while boron-based foliar fertilizer was applied at 2, 4, and 6 WAS based on the experimental layout.

Soon after sowing, metolachlor which is a pre-emergence herbicide suitable for groundnut was applied at the rate of $1.5 \mathrm{~kg}$ a.i.ha ${ }^{-1}$ using a knapsack sprayer, and thereafter, it was supplemented with manual weeding at four weeks after sowing.

The following parameters were collected during the experiments: plant height $(\mathrm{cm})$, plant spread $(\mathrm{cm})$, average number of pod and seed per plot, average weight of pod and seed, and average pod and seed yield per plot $\left(\mathrm{kg} \cdot \mathrm{ha}^{-1}\right)$.

\subsection{Laboratory Analysis of Mineral Elements of Groundnut} Seeds. Representative seed samples were taken per plot and per replicate to analyze for the levels of mineral elements contained in the seed at the crop and soil laboratory of Landmark University, Omu-Aran, Nigeria. Mature fresh seeds of groundnut were collected, oven-dried for $24 \mathrm{~h}$ at $80^{\circ} \mathrm{C}$, and ground in a Willey mill. Mineral elements were determined according to the methods recommended by the Association of Official Analytical Chemists [15]. One gram of each sample was digested using $12 \mathrm{~cm}^{-3}$ of the mix of $\mathrm{HNO}_{3}, \mathrm{H}_{2} \mathrm{SO}_{4}$, and $\mathrm{HClO}_{4}(7: 2: 1 \mathrm{v} / \mathrm{v} / \mathrm{v})$. Contents of $\mathrm{P}, \mathrm{K}$, $\mathrm{Ca}$, and $\mathrm{Mg}$ were determined by an atomic absorption spectrophotometer.

\subsection{Dry Ashing Procedure and Heavy Metal Determination of} Groundnut Seeds. Dry ashing of the seed samples collected was carried out by the procedure as described in [16]. One gram of the portion of each fruit sample was weighed into a $50 \mathrm{ml}$ porcelain crucible and gently placed into the muffle furnace and the temperature was gradually increased to $550^{\circ} \mathrm{C}$ for about 5 hours during which the muffle furnace was shut, and after 5 hours, the furnace was gently opened to allow for rapid cooling before carefully taking out the porcelain crucibles. 
The cooled ash was dissolved in a $5 \mathrm{ml}$ portion of $2 \mathrm{~N}$ hydrochloric acid $(\mathrm{HCl})$ and mixed thoroughly with a plastic rod for 15 minutes. Then, it was mixed with $50 \mathrm{ml}$ of distilled water and allowed to stand for 30 minutes before using the supernatant (or filter through Whatman No. 42 filter paper); discarding the first portions of filtrates, the aliquots were used to analyze for the heavy metals ( $\mathrm{Zn}, \mathrm{Cu}, \mathrm{Cd}, \mathrm{Fe}, \mathrm{Cr}$, and $\mathrm{Mn}$ ) using the atomic absorption spectrometry (AAS) as described in the methods of the Association of Official Analytical Chemists [15]. Heavy metals (Zn, Cu, Cd, Fe, Cr, and $\mathrm{Mn}$ ) were calculated using the following equation:

heavy metals $(\mathrm{mg} / \mathrm{kg})=\frac{\text { titre value from machine } \times \text { volume used }}{\text { molar mass }}$.

Data collected were subjected to Statistical Analysis of Variance using [17]. Significant treatment means were compared using the Duncan multiple range test at 0.05 level of probability.

\section{Results}

3.1. Soil Physical and Chemical Properties prior to Planting $(0-15 \mathrm{~cm})$. The preplanting soil analysis is as shown in Table 1 . The $\mathrm{pH}$ of the soil was strongly acidic, the nitrogen content of the soil was very low, the available phosphorus was high, and the exchangeable $\mathrm{K}$ was at moderate, while the exchangeable $\mathrm{Na}, \mathrm{Ca}$, and $\mathrm{Mg}$ were all suitable. The organic carbon and organic matter are adequate. The soil is high in sand with relatively low values in both silt and clay; hence, the textural class is sandy loam.

3.2. Chemical Properties of Boron-Based Liquid Fertilizer. Chemical analysis of the boron-based liquid fertilizer as shown in Table 2 indicated that it contained mineral elements required for plant growth and some heavy metals as essential elements.

3.3. The Effect of Zinc and Boron Fertilizers on Plant Height and Spread of Groundnut. The effect of zinc and boron on plant height and spread of groundnut is shown in Table 3. At all sampling periods, increasing rates of $\mathrm{Zn}$ fertilizer from $0-$ $8 \mathrm{~kg} \mathrm{Zn} \cdot \mathrm{ha}^{-1}$ increased plant height of groundnut though the effect was not significant. At all weeks after sampling, varying rates from $0-600 \mathrm{ml} \mathrm{B} \cdot \mathrm{ha}^{-1}$ significantly increased plant height except at 8 weeks after sowing (WAS) where application of $300 \mathrm{ml} \mathrm{B} \cdot \mathrm{ha}^{-1}$ was significantly similar to the application of $600 \mathrm{ml} \mathrm{B} \cdot \mathrm{ha}^{-1}$ and $900 \mathrm{ml} \mathrm{B} \cdot \mathrm{ha}^{-1}$. Relative to the control which gave the least value for plant spread, application of $600 \mathrm{ml} \mathrm{B} \cdot \mathrm{ha}^{-1}$ significantly increased plant spread, values of which were statistically similar with the application of $900 \mathrm{ml} \mathrm{B} \cdot \mathrm{ha}^{-1}$. There was no significant interaction between the application of zinc and boron fertilizers on plant spread.

3.4. The Effect of Zinc and Boron Fertilizers on Number, Weight, and Yield of Groundnut Pod. Number of pods, weight of pods, and yield of pods ha ${ }^{1}$ as affected by application of zinc and boron fertilizers is shown in Table 4. Higher value for number of pods, weight of pods, and pod yield $\mathrm{ha}^{-1}$ was observed at the application of $8 \mathrm{~kg} \mathrm{Zn} \cdot \mathrm{ha}^{-1}$ which was significantly different from the value obtained when $4 \mathrm{~kg} \mathrm{Zn} \cdot \mathrm{ha}^{-1}$ was applied. The control $\mathrm{Zn}$ gave the least value for the parameters measured.

As the rates of boron fertilizer increases from $0-600 \mathrm{ml}$ $\mathrm{B} \cdot \mathrm{ha}^{-1}$, the value for the parameters also increases significantly. Further increase from $600 \mathrm{ml} \mathrm{B} \cdot \mathrm{ha}^{-1}$ to $900 \mathrm{ml} \mathrm{B} \cdot \mathrm{ha}^{-1}$ increases the values for the parameters though the difference was not significant. There was a significant interaction between $\mathrm{Zn}$ and $\mathrm{B}$ on number of pods, weight of pods, and pod yield $\mathrm{ha}^{-1}$.

3.5. The Effect of Zinc and Boron Fertilizers on Number, Weight, and Yield of Groundnut Seed. Data shown in Table 4 indicated that application of $8 \mathrm{~kg} \mathrm{Zn} \cdot \mathrm{ha}^{-1}$ significantly increased number of seeds, weight of seeds, and seed yield ha ${ }^{-1}$ though the values were statistically similar with the values obtained at the application of $4 \mathrm{~kg} \mathrm{Zn} \cdot \mathrm{ha}^{-1}$. The control gave a significantly lower value for all the parameters.

Increase in the application of boron fertilizer from the control to $600 \mathrm{ml} \mathrm{B \cdot ha}{ }^{-1}$ significantly increased number of seeds, weight of seeds, and seed yield ha ${ }^{-1}$. Further increase in boron fertilizer application from 600 to $900 \mathrm{ml} \mathrm{B} \cdot \mathrm{ha}^{-1}$ increased values for the parameters though not statistically different with the application of $600 \mathrm{ml} \mathrm{B} \cdot \mathrm{ha}^{-1}$. Interaction between $\mathrm{Zn}$ and $\mathrm{B}$ was significant on the parameters.

3.6. The Effect of Zinc and Boron Fertilizers on Nutrient Content of Groundnut Seed. The effects of $\mathrm{Zn}$ and B on the nutrient contents of groundnut seeds are shown in Table 5. When compared with the control which gave the least but statistically similar values for $\mathrm{N}, \mathrm{P}$, and $\mathrm{K}$ when $4 \mathrm{~kg} \mathrm{Zn} \cdot \mathrm{ha}^{-1}$

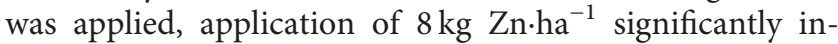
creased values for $\mathrm{N}, \mathrm{P}, \mathrm{K}$. and $\mathrm{Mg}$. Increasing application of $\mathrm{Zn}$ significantly reduced values for $\mathrm{Ca}$ though values obtained when $4 \mathrm{~kg} \mathrm{Zn} \cdot \mathrm{ha}^{-1}$ and $8 \mathrm{~kg} \mathrm{Zn} \cdot \mathrm{ha}^{-1}$ were applied were statistically similar. In a similar vein, application of $900 \mathrm{ml} \mathrm{B} \cdot \mathrm{ha}^{-1}$ significantly increased values for all the parameters tested though statistically similar with the application of $600 \mathrm{ml} \mathrm{B} \cdot \mathrm{ha}^{-1}$.

\subsection{The Effect of Zinc and Boron Fertilizers on Heavy Metal} Contents of Groundnut Seed. The effects of $\mathrm{Zn}$ and B on some heavy metal (zinc, copper, cadmium, iron, chromium, and manganese) contents in groundnut seeds are shown in Table 6. Application of zinc fertilizer from 0 to $8 \mathrm{~kg} \cdot \mathrm{ha}^{-1}$ significantly increased the contents of zinc, copper, and manganese in groundnut seeds, while the contents of iron, cadmium, and chromium were reduced.

$900 \mathrm{ml} \mathrm{B} \cdot \mathrm{ha}^{-1}$ had significantly higher values for all the heavy metal values of which was statistically similar with cadmium, iron, chromium, and manganese content in groundnut seeds when $600 \mathrm{ml} \mathrm{B} \cdot \mathrm{ha}^{-1}$ was applied There was a significant interaction between the two fertilizers. 
TABle 1: Soil physical and chemical properties prior to planting $(0-15 \mathrm{~cm})$

\begin{tabular}{lcc}
\hline \multirow{2}{*}{ Parameter } & \multicolumn{2}{c}{ Values } \\
& 2016 & 2017 \\
\hline Sand (\%) & 76.12 & 75.00 \\
Silt $(\%)$ & 12.00 & 12.85 \\
Clay $(\%)$ & 11.88 & 12.15 \\
Textural class & Sandy loam & Sandy loam \\
pH $\left(\mathrm{H}_{2} \mathrm{O}\right) 1: 1$ & 5.25 & 6.39 \\
Total N & 0.16 & 0.13 \\
O.M & 1.88 & 1.58 \\
O.C & 3.24 & 3.05 \\
\hline Exchangeable bases & & \\
K (cmol/kg) & 0.23 & 0.33 \\
Na (cmol/kg) & 0.66 & 0.43 \\
Ca (cmol/kg) & 3.97 & 3.70 \\
Mg (cmol/kg) & 1.32 & 1.41 \\
ECEC (cmol/kg) & 6.18 & 5.87 \\
Available phosphorus (mg/kg) & 21.12 & 20.55 \\
Zn (mg/kg) & 0.45 & 0.45 \\
\hline
\end{tabular}

\section{Discussion}

The productivity of groundnut depends on proper selection of variety, fertilizer management, and other management practices [18]. $\mathrm{Zn}$ and B are recognized as key elements in promoting growth, yield, and quality of groundnut. Boron (B) plays an important role in the physiological process of plants, such as cell elongation, cell maturation, meristematic tissue development, and protein synthesis [9].

Foliar application of micronutrients to plants is the most effective and safest way [19]. The need for B application in groundnut is to increase the growth, development, and at the same time to increase the yield of crops. The application of $\mathrm{B}$ also promotes the absorption of $\mathrm{N}$ by groundnut and increases the plant height, plant dry weight, and the total number of pods [10]. Application of boron-based fertilizer significantly increased the vegetative parameters of groundnut. Increased in vegetative parameters might be due the presence of nitrogen in boron ethanolamine $\left(\mathrm{C}_{2} \mathrm{H}_{10} \mathrm{BNO}_{4}\right)$ fertilizer and the effect of $\mathrm{B}$ in promoting the absorption of nitrogen in the soil which assisted in improved growth. Boron's application promoted the absorption of $\mathrm{N}$ by groundnut and thus, helped in increasing plant growth and development [10].

B plays an important role in retaining flowering and fruit setting in pulses [20]. The results also showed that yield and all the yield parameters measured during this study increased with increasing levels of B-based fertilizer. Increase in yield could be as a result of filled pods with the application of $\mathrm{B}$ fertilizer compared with the least number of unfilled pods when boron fertilizer was not applied. Chitdeshwari and Poongothai [21] observed that the positive role of B in quality improvement through its involvement in the synthesis of protein and amino acids further increased the pod yield of groundnut.

$\mathrm{Zn}$ fertilization of crops has received further attention due to widespread $\mathrm{Zn}$ malnutrition, especially in developing countries [22]. $\mathrm{Zn}$ is essential for normal plant growth and development as carbohydrates, protein metabolism, and sexual fertilization depend on $\mathrm{Zn}$ [23]. However, the $\mathrm{Zn}$ deficiency in agricultural soil caused by removal of $\mathrm{Zn}$ by crops is not fully replenished by fertilizer applications [24]. $\mathrm{Zn}$ deficiency is a common feature in many climatic regions, particularly in sandy soil, and it causes severe decreases in yield and quality of groundnut.

Zn functions in plants are largely associated with activity [25]. The result of this study revealed that increasing levels of $\mathrm{Zn}$ fertilizer from the control to $8 \mathrm{~kg} \mathrm{Zn} \cdot \mathrm{ha}^{-1}$ did not significantly increase the vegetative parameters of groundnut. This could be due to the fact that the soil is highly deficient in available $\mathrm{Zn}$ and the limit of the applied $\mathrm{Zn}$ has not been met by the test crop in the study area.

Zn plays as an activator of several enzymes in plants, and it is directly involved in the biosynthesis of growth substances such as auxin which produces more plant cells and more dry matter that in turn will be stored in seeds as a sink. Thus, the increase in seed yield is more expected [25]. Yield and yield parameters increased significantly with increasing application of zinc fertilizer up to $8 \mathrm{~kg} \mathrm{ZnSO}_{4} \cdot \mathrm{ha}^{-1}$. This might be due to the significant improvement in plant height and spread, leading to improved nodulation through activation of various enzymes and the basic metabolic rate in plants, which in turn enhanced the pod yield due to greater availability of nutrients and photosynthates. It could also be as a result of increased photosynthesis by facilitating nitrogen in leguminous plants. Ved et al.[26] stated that foliarapplied $\mathrm{Zn}$ enhances photosynthesis at early growth of plants and improves nitrogen fixation, grain protein, and yields of mungbean plants.

The study also showed that sole and combined application of $\mathrm{Zn}$ and $\mathrm{B}$ fertilizer increased the nitrogen and phosphorus content of the seeds. These results may be due to the beneficial effect of $\mathrm{B}$ and $\mathrm{Zn}$ on metabolic processes and growth which in turn reflected positively on the chemical content of groundnut seeds. Darwish et al.[27] found that application of $48 \mathrm{~kg} \mathrm{~K} 2 \mathrm{O} / \mathrm{fad}$ combined with spraying zinc (1000 ppm zinc sulphate) gave the highest seed and oil yields per fad and protein.

Major elements in the human body include oxygen, carbon, hydrogen, nitrogen, carbon, phosphorus, potassium, calcium, and magnesium. Helmenstine [28] identified the following about the elements in the human body: $\mathrm{N}$ is a component of proteins, nucleic acids, and other organic compounds; $\mathrm{Ca}$ is also found in the nervous system, muscles, and the blood where it is integral in proper membrane function, conducting nerve impulses, regulating muscle contractions, and blood clotting; and phosphorus is part of nucleic acids, energy compounds, and phosphate buffers. The element is incorporated into the bones and combines with other elements including iron, potassium, sodium, magnesium, and calcium. It is necessary for sexual function and reproduction, muscle growth, and to supply nutrients to the nerves; that $\mathrm{P}$ is important for membrane function, nerve impulses, and muscle contractions; that $\mathrm{K}$ is important for membrane function, nerve impulses, and muscle contractions; and that $\mathrm{Mg}$ is needed for strong teeth and bones.

The results of the study indicated that application of $\mathrm{Zn}$ and $B$ fertilizers increased values for all the elements $(\mathrm{N}, \mathrm{P}$, 
TABLE 2: Chemical properties of boron-based liquid fertilizer.

\begin{tabular}{lccccccccccccc}
\hline & \multicolumn{1}{c}{$\% \mathrm{w} / \mathrm{v}$} & \multicolumn{1}{c}{$\mathrm{mg} / \mathrm{L}$} & $\mathrm{mg} / \mathrm{L}$ & $\mathrm{Cl}$ \\
\hline Nutrients & $\mathrm{N}$ & $\mathrm{P}$ & $\mathrm{K}$ & $\mathrm{Ca}$ & $\mathrm{Mg}$ & $\mathrm{Fe}$ & $\mathrm{Mn}$ & $\mathrm{Cu}$ & $\mathrm{Zn}$ & $\mathrm{B}$ & $\mathrm{Cd}$ & $\mathrm{Pb}$ & $\mathrm{Cr}$ \\
Concentration & 3.01 & 0.15 & 0.04 & 0.08 & 0.10 & 0.005 & 28.0 & 1.40 & 17.0 & 12.60 & 2.40 & 5.80 & 0.10 \\
\hline
\end{tabular}

TABLE 3: Effect of application of zinc and boron fertilizers on vegetative parameters of groundnut (pooled data of 2016 and 2017 cropping seasons).

\begin{tabular}{|c|c|c|c|c|c|c|}
\hline \multirow{2}{*}{ Treatments } & \multicolumn{3}{|c|}{ Plant height } & \multicolumn{3}{|c|}{ Plant spread } \\
\hline & 4 WAS & 6 WAS & 8 WAS & 4 WAS & 6 WAS & 8 WAS \\
\hline \multicolumn{7}{|c|}{$\mathrm{ZnSO}_{4} \mathrm{~kg} \cdot \mathrm{ha}^{-1}$} \\
\hline 0 & $21.97 \mathrm{a}$ & $25.84 \mathrm{a}$ & $26.57 \mathrm{a}$ & $36.38 \mathrm{a}$ & $39.72 \mathrm{a}$ & $43.14 \mathrm{a}$ \\
\hline 4 & $22.86 a$ & $26.24 \mathrm{a}$ & $28.46 \mathrm{a}$ & $36.83 a$ & $41.08 \mathrm{a}$ & $45.14 \mathrm{a}$ \\
\hline 8 & $22.91 \mathrm{a}$ & $26.60 \mathrm{a}$ & $28.89 \mathrm{a}$ & $36.85 a$ & $41.25 \mathrm{a}$ & $45.22 \mathrm{a}$ \\
\hline \multicolumn{7}{|c|}{ Boron $\left(\mathrm{ml} \cdot \mathrm{ha}^{-1}\right)$} \\
\hline 0 & $18.58 \mathrm{c}$ & $22.40 c$ & $23.78 b$ & $28.93 c$ & $32.18 c$ & $35.71 \mathrm{c}$ \\
\hline 300 & $22.38 b$ & $25.50 \mathrm{~b}$ & $26.85 \mathrm{ab}$ & $35.85 b$ & $41.85 b$ & $44.26 \mathrm{~b}$ \\
\hline 600 & $25.09 \mathrm{a}$ & $28.72 \mathrm{a}$ & $30.70 a$ & $41.69 a$ & $45.22 \mathrm{a}$ & $50.85 a$ \\
\hline 900 & $24.26 \mathrm{a}$ & $26.26 \mathrm{a}$ & $30.55 \mathrm{a}$ & $40.26 \mathrm{ab}$ & $43.48 \mathrm{ab}$ & $47.51 \mathrm{ab}$ \\
\hline \multicolumn{7}{|l|}{ Interaction } \\
\hline $\mathrm{Zn}$ & ns & ns & ns & ns & ns & ns \\
\hline $\mathrm{B}$ & $*$ & $*$ & $*$ & $*$ & $*$ & $*$ \\
\hline $\mathrm{Zn}^{*} \mathrm{~B}$ & ns & ns & ns & ns & ns & ns \\
\hline
\end{tabular}

Means in a column under any given treatment followed by the same letters do not differ significantly at 0.05 level of probability using the Duncan multiple range test $(\mathrm{DMRT}) . \mathrm{ns}=$ not significant. ${ }^{*}$ Significant at 0.05 level of probability. WAS = weeks after sowing.

TABle 4: Effects of zinc and boron fertilizers on pod and seed yield of groundnut (pooled data of 2016 and 2017 cropping seasons).

\begin{tabular}{|c|c|c|c|c|c|c|}
\hline Treatments & $\begin{array}{l}\text { Number of pods/ } \\
\text { plant }\end{array}$ & $\begin{array}{l}\text { Pod weight/plant } \\
\text { (g) }\end{array}$ & $\begin{array}{l}\text { Pod yield (kg/ } \\
\text { ha) }\end{array}$ & $\begin{array}{l}\text { Number of seeds/ } \\
\text { plot }\end{array}$ & $\begin{array}{l}\text { Seed weight/plot } \\
\text { (g) }\end{array}$ & $\begin{array}{c}\text { Seed yield (kg } \\
\mathrm{ha}^{-1} \text { ) }\end{array}$ \\
\hline \multicolumn{7}{|c|}{$\mathrm{ZnSO}_{4} \mathrm{~kg} \cdot \mathrm{ha}^{-1}$} \\
\hline 0 & $26.10 c$ & $37.73 c$ & $3018.4 c$ & $40.18 b$ & $28.47 b$ & $2357.6 b$ \\
\hline 4 & $27.87 \mathrm{~b}$ & $42.31 \mathrm{~b}$ & $3384.8 \mathrm{~b}$ & $43.35 \mathrm{a}$ & $31.10 \mathrm{a}$ & $2508.2 b$ \\
\hline 8 & $29.40 \mathrm{a}$ & $44.91 \mathrm{a}$ & $3592.8 \mathrm{a}$ & $45.46 \mathrm{a}$ & $33.16 \mathrm{a}$ & $2672.8 \mathrm{a}$ \\
\hline \multicolumn{7}{|c|}{ Boron $\left(\mathrm{ml} \cdot \mathrm{ha}^{-1}\right)$} \\
\hline 0 & $22.39 c$ & $36.24 c$ & $2899.2 \mathrm{c}$ & $35.11 c$ & $26.46 c$ & $2116.8 \mathrm{c}$ \\
\hline 300 & $26.63 b$ & $40.02 b$ & $3201.6 b$ & $40.99 b$ & $28.44 \mathrm{~b}$ & $2275.2 b$ \\
\hline 600 & $30.09 \mathrm{a}$ & $44.22 \mathrm{a}$ & $3537.6 \mathrm{a}$ & $47.40 \mathrm{a}$ & $33.12 \mathrm{a}$ & $2669.6 \mathrm{a}$ \\
\hline 900 & $32.05 \mathrm{a}$ & $46.11 \mathrm{a}$ & $3688.0 \mathrm{a}$ & $48.16 \mathrm{a}$ & $35.29 a$ & $2823.7 \mathrm{a}$ \\
\hline \multicolumn{7}{|l|}{ Interaction } \\
\hline $\mathrm{Zn}$ & $*$ & $*$ & $*$ & $*$ & $*$ & $*$ \\
\hline B & $*$ & $*$ & $*$ & $*$ & $*$ & $*$ \\
\hline $\mathrm{Zn}^{*} \mathrm{~B}$ & $*$ & $*$ & $*$ & $*$ & $*$ & $*$ \\
\hline
\end{tabular}

Means in a column under any given treatment followed by the same letters do not differ significantly at 0.05 level of probability using the Duncan multiple range test (DMRT). ${ }^{*}$ Significant at 0.05 level of probability.

$\mathrm{K}$, and $\mathrm{Mg}$ ) except $\mathrm{Ca}$ where the value reduced with the application of $\mathrm{Zn}$. Increase in $\mathrm{N}, \mathrm{P}, \mathrm{K}$, and $\mathrm{Mg}$ could be as a result of the stimulating effect of $\mathrm{Zn} \mathrm{X} \mathrm{N}$ on wheat [29], $\mathrm{Zn}$ $\mathrm{X}$ P on St. Augustine grass [30], Zn X K on wheat [31], and $\mathrm{Zn} \mathrm{X} \mathrm{Mg} \mathrm{on} \mathrm{tung} \mathrm{trees} \mathrm{[32].} \mathrm{The} \mathrm{reduction} \mathrm{in} \mathrm{Ca} \mathrm{content} \mathrm{of}$ groundnut seeds could be attributed to the antagonistic effect of the two elements which makes $\mathrm{Ca}$ not to be available to plants. Kalyanasundaram and Mehta [33] reported reduced availability of $\mathrm{Ca}$ under high $\mathrm{Zn}$ applications. Schroeder and Balassa [34] were the first to identify that fertilizers were implicated in raising some heavy metal concentrations in food crops, and since then researchers have been urged to investigate the impact of impurities in fertilizers on crop uptake of potentially toxic elements. Studies of heavy metal uptake by plants have often revealed their accumulation at a level toxic to human health.

The result indicated that progressive increase in the values of heavy metals as a result of increase in the application of B fertilizer could be as a result of the presence of those heavy metals in the applied boron fertilizer or as a result of application of basal phosphorus fertilizer. Several studies have shown that the main source of fertilizer-derived heavy metals in soils is phosphatic fertilizers, manufactured from phosphate rocks that contain various metals as minor constituents in the ores [35]. Ebong et al. [36] found that these heavy metals in phosphatic fertilizers can subsequently accumulate in soil and become readily available to plants. 
TABle 5: Effects of Zn and B fertilizers on the nutrient content $\left(\mathrm{mg} \cdot \mathrm{kg}^{-1}\right.$ ) of groundnut seeds (pooled data of 2016 and $2017 \mathrm{cropping}$ seasons).

\begin{tabular}{|c|c|c|c|c|c|}
\hline Treatments & Nitrogen & Phosphorus & Potassium & Calcium & Magnesium \\
\hline \multicolumn{6}{|c|}{$\mathrm{ZnSO}_{4} \mathrm{~kg} \cdot \mathrm{ha}^{-1}$} \\
\hline 0 & $0.37 b$ & $0.82 b$ & $0.75 b$ & $2.56 \mathrm{a}$ & $4.86 c$ \\
\hline 4 & $0.38 b$ & $0.84 b$ & $0.77 b$ & $2.50 \mathrm{~b}$ & $5.59 \mathrm{~b}$ \\
\hline 8 & $0.40 \mathrm{a}$ & $0.90 \mathrm{a}$ & $0.83 a$ & $2.49 \mathrm{~b}$ & $5.86 \mathrm{a}$ \\
\hline \multicolumn{6}{|c|}{ Boron $\left(\mathrm{ml} \cdot \mathrm{ha}^{-1}\right)$} \\
\hline 0 & $0.30 \mathrm{c}$ & $0.73 c$ & $0.71 \mathrm{c}$ & $2.64 b$ & $3.86 c$ \\
\hline 300 & $0.35 b$ & $0.87 \mathrm{~b}$ & $0.76 b$ & $2.70 \mathrm{a}$ & $4.63 b$ \\
\hline 600 & $0.39 \mathrm{a}$ & $1.03 \mathrm{a}$ & $0.81 \mathrm{a}$ & $2.71 \mathrm{a}$ & $5.06 \mathrm{a}$ \\
\hline 900 & $0.40 \mathrm{a}$ & $0.98 \mathrm{a}$ & $0.84 \mathrm{a}$ & $2.71 \mathrm{a}$ & $5.04 \mathrm{a}$ \\
\hline \multicolumn{6}{|l|}{ Interaction } \\
\hline $\mathrm{Zn}$ & $*$ & $*$ & $*$ & $*$ & $*$ \\
\hline $\mathrm{B}$ & $*$ & $*$ & $*$ & $*$ & $*$ \\
\hline $\mathrm{Zn}^{*} \mathrm{~B}$ & $*$ & $*$ & $*$ & $*$ & $*$ \\
\hline
\end{tabular}

Means in a column under any given treatment followed by the same letters do not differ significantly at 0.05 level of probability using the Duncan multiple range test (DMRT). *Significant at 0.05 level of probability.

TABLE 6: Effect of zinc and boron fertilizers on some heavy metal concentrations $\left(\mathrm{mg}^{\mathrm{kg}} \mathrm{kg}^{-1}\right.$ ) in groundnut seeds (Pooled data of 2016 and 2017 cropping seasons).

\begin{tabular}{|c|c|c|c|c|c|c|}
\hline Treatment & Zinc & Copper & Cadmium & Iron & Chromium & Manganese \\
\hline \multicolumn{7}{|l|}{$\mathrm{ZnSO}_{4} \mathrm{~kg} \cdot \mathrm{ha}^{-1}$} \\
\hline 0 & $0.0227 c$ & $0.0355 c$ & $0.1763 a$ & $0.2340 \mathrm{a}$ & $0.0225 a$ & $0.1110 c$ \\
\hline 4 & $0.0440 \mathrm{~b}$ & $0.0370 \mathrm{~b}$ & $0.1755 b$ & $0.2330 \mathrm{~b}$ & $0.0210 \mathrm{~b}$ & $0.1120 \mathrm{~b}$ \\
\hline 8 & $0.0450 \mathrm{a}$ & $0.0385 a$ & $0.1750 \mathrm{~b}$ & $0.2325 b$ & $0.0205 b$ & $0.1128 \mathrm{a}$ \\
\hline \multicolumn{7}{|l|}{ Boron $\left(\mathrm{ml} \cdot \mathrm{ha}^{-1}\right)$} \\
\hline 0 & $0.0430 c$ & $0.0307 c$ & $0.1637 \mathrm{c}$ & $0.2283 b$ & $0.0210 \mathrm{~b}$ & $0.0927 \mathrm{c}$ \\
\hline 300 & $0.0480 \mathrm{~b}$ & $0.0307 c$ & $0.1827 b$ & $0.2493 b$ & $0.0223 b$ & $0.1177 b$ \\
\hline 600 & $0.0485 b$ & $0.0470 \mathrm{~b}$ & $0.2000 \mathrm{a}$ & $0.2983 a$ & $0.0347 \mathrm{a}$ & $0.1340 \mathrm{a}$ \\
\hline 900 & $0.0572 \mathrm{a}$ & $0.0563 \mathrm{a}$ & $0.2012 \mathrm{a}$ & $0.2997 a$ & $0.0350 \mathrm{a}$ & $0.1415 a$ \\
\hline \multicolumn{7}{|l|}{ Interaction } \\
\hline $\mathrm{Zn}$ & $*$ & * & $*$ & * & $*$ & $*$ \\
\hline $\mathrm{B}$ & * & $*$ & * & $*$ & * & $*$ \\
\hline $\mathrm{Zn}^{*} \mathrm{~B}$ & $*$ & $*$ & $*$ & $*$ & $*$ & $*$ \\
\hline${ }^{*} \mathrm{FAO} / \mathrm{WHO}$ & 99.4 & 10 & 0.2 & 0.3 & 1.30 & 0.5 \\
\hline
\end{tabular}

Means in a column under any given treatment followed by the same letters do not differ significantly at 0.05 level of probability using the Duncan multiple range test (DMRT). ${ }^{*}$ Significant at 0.05 level of probability. ${ }^{*} \mathrm{FAO} / \mathrm{WHO}(2010)$ recommended limit.

It was observed from this research work that application of $\mathrm{Zn}$ and $\mathrm{B}$ fertilizers at all rates did not increase the concentration of all the heavy metals in groundnut seeds above the safe limit as recommended by the Joint FAO/WHO Expert Committee on food additives to ensure the safety of the consumers [37].

\section{Conclusion}

The effect of zinc was not significant on the vegetative parameters, but application of $8 \mathrm{~kg} \mathrm{Zn} \cdot \mathrm{ha}^{-1}$ significantly increased number of seeds, weight of seeds, seed yield per hectare, and seed quality. Application of 600 and $900 \mathrm{ml}$ $\mathrm{B} \cdot \mathrm{ha}^{-1}$ gave higher but statistically similar values for vegetative parameters, yield, and yield parameters, while $600 \mathrm{ml}$ $\mathrm{B} \cdot \mathrm{ha}^{-1}$ significantly improved the seed quality. Results also indicated that application of $\mathrm{Zn}$ and B did not increase the concentration of heavy metals in groundnut seeds beyond the safe limit as recommended by the Joint FAO/WHO Expert Committee on food additives to ensure the safety of the consumers.

\section{Acknowledgments}

The research was funded by the Teaching and Research Farm of Landmark University, Nigeria.

\section{Conflicts of Interest}

The authors declare that there are no conflicts of interest regarding the publication of this paper.

\section{References}

[1] ICRISAT, "Grain legumes production, consumption and trade trends in developing countries- an assessment \& synthesis," 2016, http://dataverse.icrisat.org/dvn/dv/MIP/faces/ study/StudyPage.xhtml?globalId=hdl:11038/.

[2] FAO, FAOSTAT, 2011, http://www.fao.org/faostat/en/\#home.

[3] A. N. Waqar Ahmad, "Role of boron: a review," Journal of Agricultural Research, vol. 47, no. 3, pp. 329-338, 2009.

[4] M. J. Malakouti, "The effect of micronutrients in ensuring efficient use of macronutrients," Turkish Journal of Agriculture and Forestry, vol. 32, pp. 215-220, 2008. 
[5] H. Marschner, Mineral Nutrition of Higher Plant, Academic Press, Cambridge, MA, USA, 1995.

[6] J. Carroll, "Gardening know how from gardening know how," 2015, http://www.gardeningknowhow.com.

[7] R. M. Welch, "Farming for nutritious foods: agricultural technologies for improved human health," in Proceedings of the IFA-FAO Agricultural Conference, Rome, Italy, March 2003.

[8] Q. U. Zaman and A. W. Schumann, "Nutrient management zones for citrus based on variation in soil properties and tree performance," Precision Agriculture, vol. 7, no. 1, pp. 45-63, 2006.

[9] K. Mengel and E. A. Kirkby, Principles of Plant Nutrition, vol. 125, International Potash Institute, Bernlin, Switzerland, 3rd edition, 1982.

[10] R. F. Jing, Q. G. Zhang, L. F. Han, F. S. Zhang, and X. Q. Wei, "Effect of boric fertilizer on peanut absorption of boron and nitrogen," Soils, vol. 26, pp. 83-86, 1994.

[11] V. K. Suri, A. K. Choudhary, G. Chander, and T. S. Verma, "Influence of vesicular arbuscular mycorrhizal fungi and applied phosphorus on root colonization in wheat and plant nutrient dynamics in a phosphorus-deficient acid alfisol of Western Himalayas," Communications in Soil Science and Plant Analysis, vol. 42, no. 10, pp. 1077-1186, 2011.

[12] D. Elayaraja and R. Singaravel, "Zinc and boron application on groundnut yield and nutrient uptake in coastal sandy soils," International Research Journal Of Chemistry, vol. 10, no. 2, pp. 17-23, 2016.

[13] H. O. Salih, "Effect of foliar fertilization of Fe, B and $\mathrm{Zn}$ on nutrient concentration and seed protein of cowpea "vigna unguiculata"," IOSR Journal of Agriculture and Veterinary Science, vol. 6, no. 3, pp. 42-46, 2013.

[14] V. Pooniya and Y. S. Shivay, "Enrichment of basmati rice grain and straw with zinc and nitrogen through ferti-fortification and summer green manuring under Indo-Gangetic plains of India," Journal of Plant Nutrition, vol. 36, no. 1, pp. 91-117, 2013.

[15] Association of Official Analytical Chemists, Official Methods of Analysis of the Association of Official's Analytical Chemists, Association of Official Analytical Chemists, Arlington, VA, USA, 17th edition, 2003.

[16] H. D. Chapman and R. F. Pratt, Methods Analysis for Soil, Plant and Water, University of California's Division of Agriculture and Natural Resources, Los Angeles, CA, USA, 1978.

[17] Software for Statistical Analysis, SAS User's Guide: Statistics, SAS Institute, Cary, NC, USA, 2000.

[18] A. C. Lourduraj, "Nutrient management in groundnut (Arachis hypogaea L.) cultivation-a review," Agricultural Research Review, vol. 20, no. 1, pp. 14-20, 1999.

[19] A. A. Aghtape, A. Ghanbari, A. Sirousmehr, B. Siahsar, M. Asgharipour, and A. Tavssoli, "Effect of irrigation with wastewater and foliar fertilize application on some forage characteristics of foxtail millet (Setaria italica)," International Journal of Plant Physiology and Biochemistry, vol. 3, no. 3, pp. 34-42, 2011.

[20] L. Zhang, "Effects of foliar applications of boron and dimilin on soybean yield," Mississippi Agricultural and Forestry Experiment Station, Research Report, vol. 22, no. 16, pp. 1-5, 2001.

[21] T. Chitdeshwari and S. Poongothai, "Yield of groundnut and its nutrient uptake as influenced by zinc, boron and sulphur," Agricultural Science Digest, vol. 23, no. 4, pp. 263-266, 2003.
[22] R. S. Gibson, "Zinc deficiency and human health: etiology, health consequences and future solutions," Plant and Soil, vol. 361, no. 1-2, pp. 291-299, 2003.

[23] A. C. F. Vasconcelos, C. W. A. Nascimento, and F. C. Filho, "Distribution of zinc in maize plants as a function of soil and foliar Zn supply," International Research Journal of Agricultural Science and Soil Science, vol. 1, no. 1, pp. 1-5, 2011.

[24] A. Akay and N. Koleli, "Interaction between cadmium and zinc in barley (Hordeum vulgare L.) grown under field conditions," Bangladesh Journal of Botany, vol. 36, no. 1, pp. 13-19, 1970.

[25] R. M. Devlin and F. H. Withan, Plant Physiology, Wadsworth Publishing Company. A Division of Wadsworth. Inc, Belmont, CA, USA, 4th edition, 1983.

[26] R. Ved, S. K. Misra, and R. M. Upadhyay, "Effects of sulphur, zinc and biofertilizers on the quality characteristics of mungbean," Indian Journal of Pulses Research, vol. 15, no. 2, pp. 139-141, 2002.

[27] D. S. Darwish, El-G. El-Gharreib, M. A. El-Hawary, and O. A. Rafft, "Effect of some macro and micronutrients application on peanut production in a saline soil in el-faiyum governorate," Egyptian Journal of Applied Sciences, vol. 17, pp. 17-32, 2002.

[28] A. M. Helmenstine, "Elements in the human body and what they do," ThoughtCo, 2018, https://www.thoughtco.com/ elements-in-the-human-body-4050823.

[29] Y. F. Xu, S. C. Yue, Y. Q. Zhang et al., "Grain and shoot zinc accumulation in winter wheat affected by nitrogen management," Plant and Soil, vol. 361, no. 1-2, pp. 153-163, 2012.

[30] R. X. Cao, L. Q. Ma, M. Chen, S. P. Singh, and W. G. Harris, "Phosphate-induced metal immobilization in a contaminated site," Environmental Pollution, vol. 122, no. 1, pp. 19-28, 2003.

[31] M. Arif, M. Tasneem, and F. Bashir, "Evaluation of different levels of potassium and zinc fertilizer on the growth and yield of wheat," International Journal of Biosensors \& Bioelectronics, vol. 3, no. 2, pp. 242-246, 2017.

[32] S. Merrill Jr., G. F. Potter, and R. T. Brown, "Responses of tung trees on Lakeland fine sand to less common elements," Proceedings of American Society of Horticultural Science, vol. 72, pp. 94-102, 1953.

[33] N. K. Kalyanasundaram and B. V. Mehta, "Availability of zinc, phosphorus and calcium in soils treated with varying levels of zinc and phosphate-a soil incubation study," Plant and Soil, vol. 33, no. 1-3, pp. 699-706, 1970.

[34] H. A. Schroeder and J. J. Balassa, "Cadmium: uptake by vegetables from superphosphate in soil," Science, vol. 140, no. 3568, pp. 819-820, 1963.

[35] A. K. Kpomblekou and M. A. Tabatabai, "Metal contents of phosphate rocks," Communications in Soil Science and Plant Analysis, vol. 25, no. 17-18, pp. 2871-2882, 1994.

[36] G. A. Ebong, M. M. Akpan, and V. N. Mkpenie, "Heavy metal contents of municipal and rural dumpsite soils and rate of accumulation by carica papaya and talinum triangularein uyo, Nigeria," E-Journal of Chemistry, vol. 5, no. 2, pp. 281-290, 2008.

[37] JECFA. Joint FAO/WHO Expert Committee on Food Additives, "Evaluation of certain food additives," Fifty Ninth Report of the Joint FAO/WHO Expert Committee on Food Additives, World Health Organization, Geneva, Switzerland, 2010. 


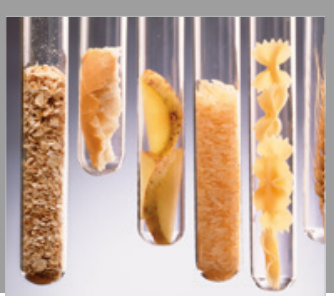

International Journal of Food Science

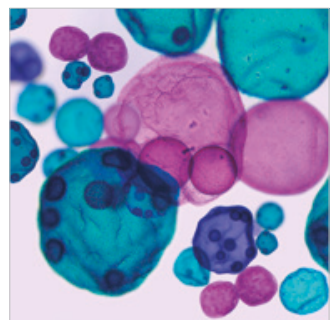

International Journal of Microbiology
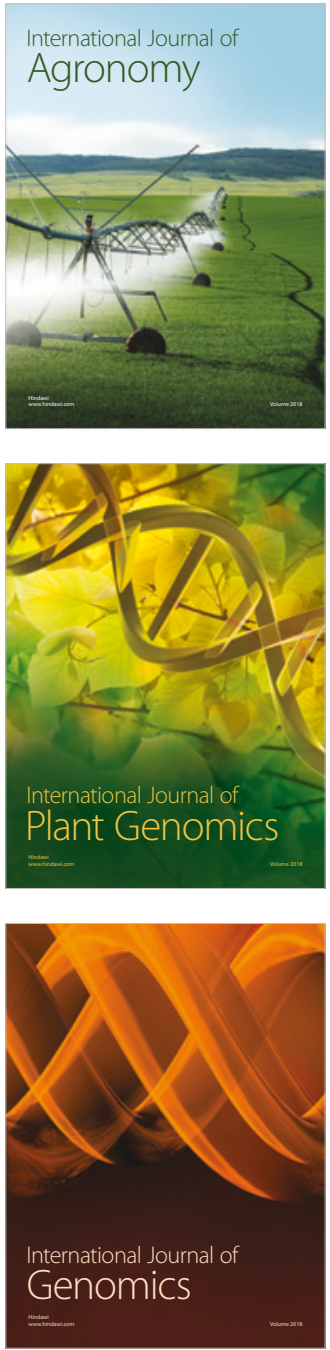

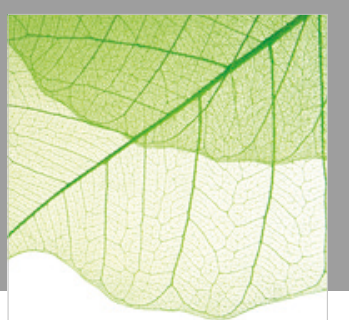

Journal of Botany
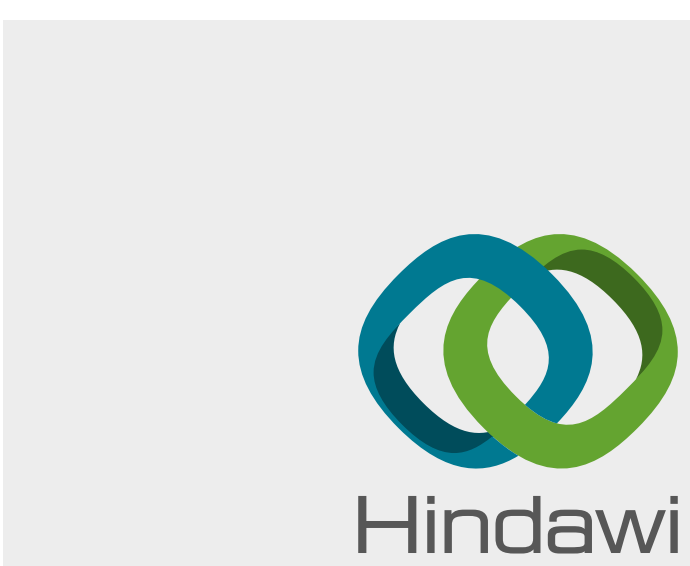

Submit your manuscripts at

www.hindawi.com
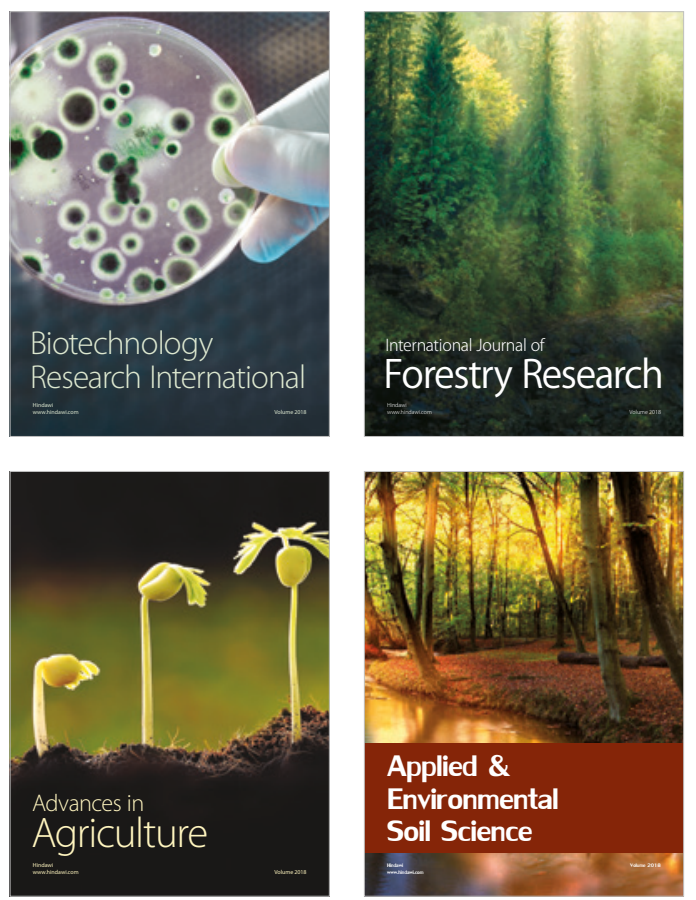

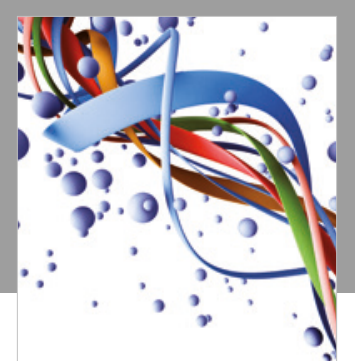

Scientifica

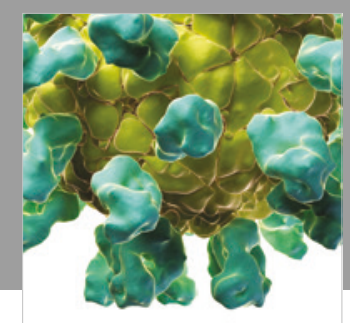

Veterinary Medicine International

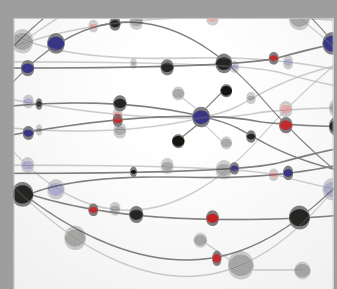

The Scientific World Journal
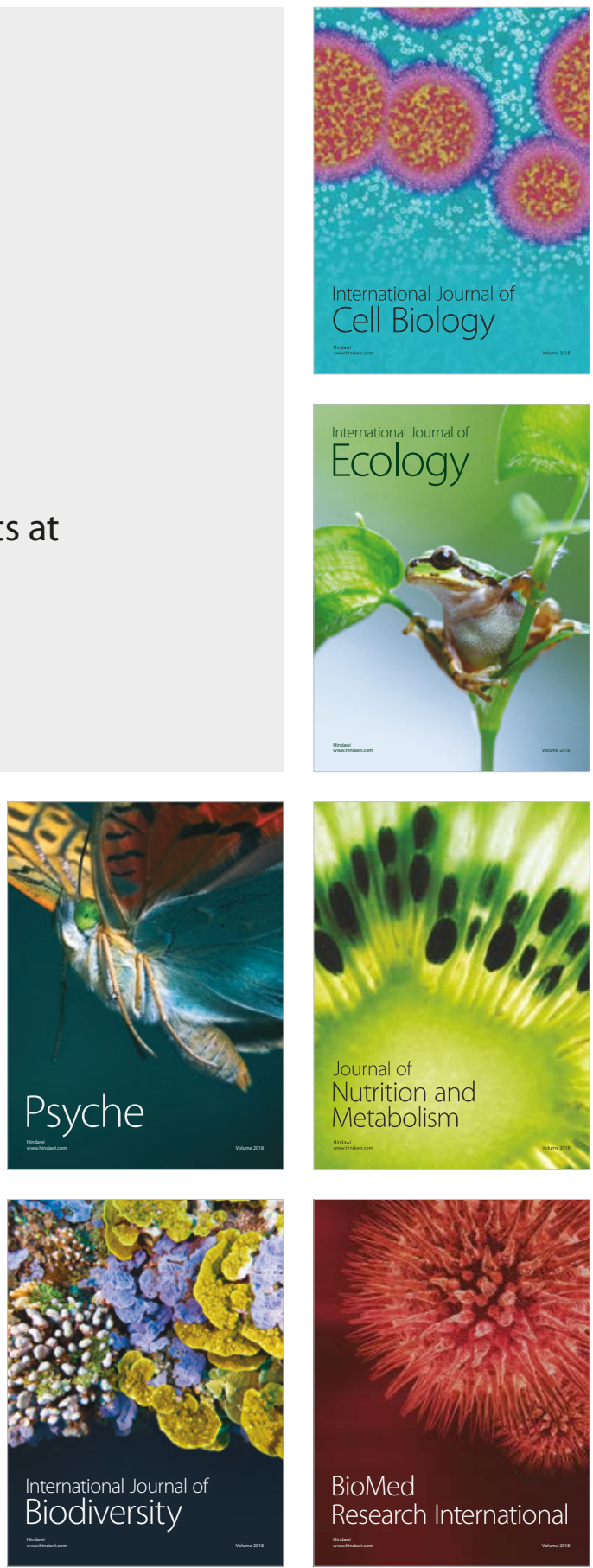